\title{
Development and characterization of microsatellite loci in a threatened marine fish, Cheilinus undulatus (humphead wrasse)
}

\author{
J. Hu ${ }^{1,2,3}$, X.P. Zhu ${ }^{1,3}$, J. Luo ${ }^{3}$, S.W. Yin ${ }^{1}$, Y.H. Peng ${ }^{3}$, Y.L. Hu ${ }^{1}$ and F. Zhu ${ }^{1,3}$ \\ ${ }^{1}$ College of Life Sciences, Nanjing Normal University, Nanjing, Jiangsu, \\ China \\ ${ }^{2}$ Tropical Fishes Research and Development Center, \\ South China Sea Fisheries Research Institute, \\ Chinese Academy of Fishery Sciences, Sanya, Hainan, China \\ ${ }^{3}$ Key Laboratory of Tropical Biological Resources of Ministry of Education, \\ Ocean College, Hainan University, Haikou, China \\ Corresponding author: S.W. Yin \\ E-mail: yinshaowu@163.com
}

Genet. Mol. Res. 12 (3): 2633-2636 (2013)

Received August 27, 2012

Accepted March 15, 2013

Published July 30, 2013

DOI http://dx.doi.org/10.4238/2013.July.30.2

\begin{abstract}
Cheilinus undulatus (humphead wrasse) is a marine fish distributed widely throughout the tropical Indo-Pacific. It has been listed as vulnerable in the IUCN Red Data Book and in CITES Appendix II four times. Fifteen microsatellite loci were isolated and characterized for this species. The number of alleles ranged from 3 to 15 per locus, and the observed and expected heterozygosity ranged between 0.0323 0.7742 and $0.2597-0.8773$, respectively. The polymorphism information content ranged from $0.2353-0.8520$. Four microsatellite loci deviated significantly from Hardy-Weinberg expectations. No significant linkage disequilibrium was found among any of the loci. These microsatellite loci will be useful for future investigations of genetic variation in the wrasse population.
\end{abstract}

Key words: Humphead wrasse; Cheilinus undulatus; Microsatellite; DNA 


\section{INTRODUCTION}

The humphead wrasse (Cheilinus undulatus Rüppell, 1835) is a large coral reef fish distributed widely throughout the tropical Indo-Pacific. It is the largest living member of the family Labridae, with a maximum size exceeding $2 \mathrm{~m}$ and $190 \mathrm{~kg}$ (Sadovy et al., 2003). The humphead wrasse is one of the most valuable fish in the live reef food fish trade in Asia (Scales et al., 2007). This species was listed as vulnerable in the IUCN Red Data Book and in CITES Appendix II. It was classified in this way due to concerns over rapidly declining population numbers in many areas, particularly within the last decade (Sadovy et al., 2003). Until now, studies of $C$. undulatus have mainly focused on their geographical distribution, taxonomy, morphology, ecological habits, reproduction, and protection (Wada et al., 1993; Donaldson and Sadovy, 2001; Chateau and Wantiez, 2007; Pantelis et al., 2011). Little is known about genetic relationships at different geographical scales, even though this information may provide new insight for the management and construction of protected areas. The use of polymorphic DNA markers is important for developing conservation strategies. Because of the lack of DNA markers in this species, we here report 15 polymorphic microsatellite loci isolated from the genomic DNA of the humphead wrasse to facilitate population genetic studies in this species.

\section{MATERIAL AND METHODS}

Genomic DNA was extracted from fish tail fins using the standard phenol-chloroform method. This DNA was then digested with Bsp143I. The digested products, 400-1000 bp in size, were separated on $1.0 \%$ low melting point agarose gel. A synthesized adaptor (LinkerA: 5'-GCGGTACCCGGGAAGCTTGG-3'; LinkerB: 5'-GATCCCAAGCTTCCCGGGTACGC-3') was ligated to the size-selected DNA fragments using T4 DNA ligase. Fragments containing microsatellite DNA were enriched by hybridization with a biotinylated (CA) ${ }_{15}$ probe followed by isolation using streptavidin-coated magnetic beads (Promega).

The microsatellite-enriched DNA was amplified with the LinkerA primer, and then the product was ligated into apMD18-T vector(Takara). Vectors were then transformed into competent E. coli $\mathrm{DH} 5 \alpha$ cells and plated onto Luria-Bertani agar plates containing $60 \mathrm{mg} / \mathrm{L}$ ampicillin, 24 $\mathrm{mg} / \mathrm{L}$ isopropyl-thio- $\beta$-galactoside, and $40 \mathrm{mg} / \mathrm{L} \mathrm{X}$-Gal. The colonies were each subjected to 3 independent polymerase chain reaction (PCR) screenings. The first PCR was carried out using 2 universal sequencing primers on the vector(M13:5'-CGCCAGGGTTTTCCCAGTCACGAC-3'; RV-M: 5'-GAGCGGATAACAATTTCACACAGG-3'), the second using (CA) ${ }_{15}$ oligo-nucleotide and the primer M13, and the third using $(\mathrm{CA})_{15}$ oligo-nucleotide and the primer RV-M.

A colony was considered desirable for sequencing only if the PCR product amplified by both sequencing primers was different from the product amplified by either the (CA) oligo-nucleotide and the forward sequencing primer or the (CA) $)_{15}$ oligo-nucleotide and the reverse sequencing primer. A total of 132 colonies were selected and sequenced using an ABI 3730 analyzer (Applied Biosystems). From the 78 microsatellite sequences obtained, we ultimately identified 20 microsatellite markers using the PRIMER PREMIER 5.0 software (Rychlik and Rhoads, 1989). Five of the 20 loci either failed to amplify product or amplified non-specific products in some individuals.

To characterize the microsatellites, genomic DNA was isolated from 31 wild individuals from LingShui City, Hainan Province, 18.2346N 109.5158E. PCR amplifications were 
performed under the following conditions: an initial predenaturation at $95^{\circ} \mathrm{C}$ for $5 \mathrm{~min}$ followed by 30 cycles of denaturation at $94^{\circ} \mathrm{C}$ for $30 \mathrm{~s}, 30 \mathrm{~s}$ of annealing at temperatures listed in Table 1 , and extension at $72^{\circ} \mathrm{C}$ for $30 \mathrm{~s}$, followed by a final extension at $72^{\circ} \mathrm{C}$ for $5 \mathrm{~min}$. After PCR amplification, the obtained DNA samples were subject to electrophoresis on $8 \%$ non-denaturing polyacrylamide gels at $12 \mathrm{~W}$ for 3-4 $\mathrm{h}$.

Genetic diversity was assessed by calculating the number of alleles per locus, observed, and expected heterozygosity, using the Popgene32 software package (Yeh et al., 1999). Hardy-Weinberg equilibrium (HWE) and linkage disequilibrium analysis were tested using Arlequin 3.11 (Excoffier et al., 2005). Finally, PIC-CALC was used to calculate the polymorphism information content.

Table 1. Primer sequences and characterization of 15 polymorphic microsatellite loci for Cheilinus undulatus.

\begin{tabular}{|c|c|c|c|c|c|c|c|c|c|c|}
\hline Locus & Primer sequence $\left(5^{\prime}-3^{\prime}\right)$ & $\mathrm{Ta}\left({ }^{\circ} \mathrm{C}\right)$ & Repeat motif & $N_{\mathrm{A}}$ & $N_{\mathrm{E}}$ & $H_{\mathrm{O}}$ & $H_{\mathrm{E}}$ & PIC & $\begin{array}{l}\text { P value } \\
\text { (HWE) }\end{array}$ & $\begin{array}{l}\text { GenBank } \\
\text { accession }\end{array}$ \\
\hline & $\begin{array}{l}\text { F: GTTCTCAGCAGCCATCCT } \\
\text { R: CGATTAGACCCAAACCCT }\end{array}$ & 56 & $(\mathrm{AC})_{7} \mathrm{C}_{2}(\mathrm{AC})_{5}$ & 3 & & & & .2353 & 0.66777 & HQ995574 \\
\hline A18 & $\begin{array}{l}\text { F: TGCTCCAGGTTCTCATCC } \\
\text { R: AAGCCTTCTTGCTGTTGT }\end{array}$ & 58 & $(\mathrm{CA})_{12}$ & 10 & 2.9569 & 0.3548 & 0.6727 & 0.6385 & 0.12084 & HQ995581 \\
\hline B22* & $\begin{array}{l}\text { F: AACAGTGAGTGGGGAAAA } \\
\text { R: AAAGTGGTGCTAGTGGAA }\end{array}$ & 56 & $(\mathrm{AC})_{11} \mathrm{CCACC}(\mathrm{CA})_{6}$ & 6 & 4.3682 & 0.6452 & 0.7837 & 0.7339 & $0.03959 *$ & HQ995639 \\
\hline A63* & $\begin{array}{l}\text { F: TTAGGCTGTG } \\
\text { R: GCAGATTGTT }\end{array}$ & 57 & $\begin{array}{c}(\mathrm{TG})_{13} \ldots(\mathrm{CT})_{6} \ldots \\
(\mathrm{CT})_{9}(\mathrm{GTCT})_{3}(\mathrm{TC})_{19}\end{array}$ & 7 & 4.7811 & 0.7742 & 0.8038 & 0.7613 & $0.00512 *$ & HQ995601 \\
\hline A66* & $\begin{array}{l}\text { F: CATTGTTC } \\
\text { R: CCAGTTG }\end{array}$ & 58 & $(\mathrm{GT})_{13}$ & 6 & 2.5390 & 0.0323 & 0.6161 & 0.5726 & $0.01332 *$ & HQ995603 \\
\hline A67 & $\begin{array}{l}\text { F: TT } \\
\text { R: GA }\end{array}$ & 58 & $(\mathrm{GT})_{5} \mathrm{CA}(\mathrm{GT})_{5}$ & 6 & 4.1245 & 0.6774 & 0.7700 & 0.7025 & 0.15373 & HQ99560 \\
\hline A75 & $\begin{array}{l}\text { F: AAGCCTCGCCAAACTAAA } \\
\text { R: CTACTAACGTGCGCTAAAT }\end{array}$ & 57 & $\begin{array}{l}(\mathrm{TG})_{5} \mathrm{TAG}(\mathrm{GT})_{3} \mathrm{G}_{2} \\
(\mathrm{GT})_{4} \mathrm{G}_{2}(\mathrm{GT})_{7}\end{array}$ & 7 & 3.5073 & 0.5484 & 0.7266 & 0.6787 & 0.13770 & HQ995608 \\
\hline A101 & $\begin{array}{l}\text { F: CCGGTTCTGACTCTTCTC } \\
\text { R: GGTCATTTACAACCCAAGT }\end{array}$ & 58 & $(\mathrm{TG})_{9}$ & 5 & 2.9615 & 0.7097 & 0.6732 & 0.6211 & 0.11440 & HQ995616 \\
\hline A106 & $\begin{array}{l}\text { F: TCTGTCCCGTGTCCATCT } \\
\text { R: CAGTTTTGACATTGTCCCA }\end{array}$ & 58 & $(\mathrm{AC})_{10}$ & 15 & 7.3080 & 0.6774 & 0.8773 & 0.8520 & 0.87594 & HQ995620 \\
\hline A112 & $\begin{array}{l}\text { F: TGAGTCAGGATTAGGTGGAT } \\
\text { R: AAGGCAGAACCCTGGAGC }\end{array}$ & 58 & $(\mathrm{GT})_{8}$ & 13 & 4.0463 & 0.3871 & 0.7652 & 0.7341 & 0.62642 & HQ995621 \\
\hline A119* & $\begin{array}{l}\text { F: AGCAGGGCTCAACATAACA } \\
\text { R: TGGATTCCTGGAGTTTGC }\end{array}$ & 57 & $(\mathrm{TG})_{9} \ldots(\mathrm{GTCT})_{5}$ & 6 & 4.6764 & 0.5806 & 0.7990 & 0.7535 & $0.01402 *$ & HQ995622 \\
\hline A120 & $\begin{array}{l}\text { F: CGGGAGGGAAGAATCACA } \\
\text { R: AACAGGCCGACACCAAGT }\end{array}$ & 60 & $(\mathrm{AC})_{5}$ & 13 & 4.6764 & 0.4194 & 0.7990 & 0.7717 & 0.27378 & HQ995623 \\
\hline A151 & $\begin{array}{l}\text { F: CAAGGCCGACCTGTCAAA } \\
\text { R: GGTTATCGTGGCGTGTCC }\end{array}$ & 57 & $(\mathrm{GT})_{6} \ldots(\mathrm{TC})_{5}$ & 8 & 2.7855 & 0.0645 & 0.6515 & 0.7383 & 0.07287 & HQ995632 \\
\hline $\mathrm{B} 30(2)$ & $\begin{array}{l}\text { F: AGAGTTTGGCTGTAAGGG } \\
\text { R: AGGAATGTTGAGAATCGTG }\end{array}$ & 58 & $(\mathrm{GT})_{12}$ & 9 & 3.0900 & 0.3871 & 0.6875 & 0.6524 & 0.09602 & HQ995642 \\
\hline T462 & $\begin{array}{l}\text { F: ACTTCAGTCCAACCATCTCA } \\
\text { R: AGCACGAGCGTCAGGAAC }\end{array}$ & 56 & $(\mathrm{ATCT})_{16}$ & 12 & 6.8889 & 0.6452 & 0.8689 & 0.8395 & 0.81543 & HQ995654 \\
\hline
\end{tabular}

*Indicate a significant deviation from Hardy-Weinberg equilibrium $(\mathrm{HWE}) . \mathrm{F}=$ forward primers; $\mathrm{R}=$ reverse primers; Ta $=$ PCR annealing temperature; $N_{\mathrm{A}}=$ number of alleles; $N_{\mathrm{E}}=$ number of effective alleles; $H_{\mathrm{O}}=$ observed heterozygosity; $H_{\mathrm{E}}=$ expected heterozygosity; $\mathrm{PIC}=$ polymorphism information content.

\section{RESULTS AND DISCUSSION}

The primer sequences and other characteristics are listed in Table 1 . The number of alleles ranged from 3 to 15 and observed heterozygosity ranged from 0.0323 to 0.7742 . Four microsatellite loci deviated significantly from Hardy-Weinberg expectations (HWE), but no deviations from HWE were detected after Bonferroni's correction ( $\mathrm{P}>0.05$, for all 15 alleles), 
indicating a significant deficit of heterozygotes. All four loci were prone to null alleles $(\mathrm{P}<$ 0.05). The presence of excess null alleles may have biased the results of the HWE test (Jones et al., 1998), or it may be related to a particularity of $C$. undulatus, which is highly restricted to the coral reef habitat and is sensitive to environmental change. No significant disequilibrium within samples was found, indicating that genotypes at pairs of microsatellites appear to be randomly associated and are inherited in a Mendelian fashion. These genetic markers will be useful for further evaluations of spatial and temporal genetic variation and conservation management of the humphead wrasse.

\section{ACKNOWLEDGMENTS}

Research supported by the National Natural Science Foundation of China (\#40966003), the National R\&D Program of China (\#2007BAD29B03), the Nature Science Foundation of Hainan Province of China (\#808122), and a project funded by the Academic Program Development of Jiangsu Higher Education Institutions (PAPD), the State High-Technology R\&D Project of China (\#2012AA10A414).

\section{REFERENCES}

Chateau O and Wantiez L (2007). Site fidelity and activity patterns of a humphead wrasse, Cheilinus undulatus (Labridae), as determined by acoustictelemetry. Environm. Biol. Fish. 80: 503-508.

Donaldson TJ and Sadovy Y (2001). Threatened fishes of the world: Cheilinus undulatus Rüppell, 1835 (Labridae). Environm. Biol. Fish. 62: 428.

Excoffier L, Laval G and Schneider S (2005). Arlequin (version 3.0): an integrated software package for population genetics data analysis. Evol. Bioinform. Online 1: 47-50.

Pantelis K, Giorgos R and Pascal D (2011). Enteromyxum leei (Myxozoa), a lethal intruder of tropical pet fish: first case in humphead wrasse, Cheilinus undulatus (Rüppell, 1835). J. Exotic Pet Med. 20: 138-143.

Jones AG, Stockwell CA, Walker D and Avise JC (1998). The molecular basis of a microsatellite null allele from the white sands pupfish. J. Hered. 89: 339-342.

Rychlik W and Rhoads RE (1989). A computer program for choosing optimal oligonucleotides for filter hybridization, sequencing and in vitro amplification of DNA. Nucleic Acids Res. 17: 8543-8551.

Sadovy Y, Kulbicki M, Labrosse P, Letourneur Y, et al. (2003). The humphead wrasse, Cheilinus undulatus: synopsis of a threatened and poorly known giant coral reef fish. Rev. Fish Biol. Fish. 13: 327-364.

Scales H, Balmford A and Manica A (2007). Impacts of the live reef fish trade on populations of coral reef fish off northern Borneo. Proc. Biol. Sci. 274: 989-994.

Wada S, Hatai K, Tanaka E and Kitahara T (1993). Mixed infection of an acid-fast bacterium and an imperfect fungus in a Napoleon fish (Cheilinus undulatus). J. Wildl. Dis. 29: 591-595.

Yeh FC, Yang RC and Boyle T (1999). POPGENE Version 1.3.1. Microsoft Window-Bases Freeware for Population Genetics Analysis. University of Alberta and the Centre for International Forestry Research. Available at [www. ualberta.ca/ fyeh/]. 